\title{
Unleashing the power of NK cells in anticancer immunotherapy
}

\author{
Meike Vogler $^{1}\left([)\right.$ Senthan Shanmugalingam ${ }^{1} \cdot$ Vinzenz Särchen $^{1} \cdot$ Lisa Marie ReindI ${ }^{2,3}$ (D) Victoria Grèze $\mathrm{V}^{2,3}$. \\ Leon Buchinger ${ }^{2,3} \cdot$ Michael Kühn $^{4} \cdot$ Evelyn Ullrich ${ }^{2,3,5}$
}

Received: 19 May 2021 / Revised: 15 July 2021 / Accepted: 16 July 2021 / Published online: 9 August 2021

(c) The Author(s) 2021

\begin{abstract}
Due to their physiological role in removing damaged cells, natural killer (NK) cells represent ideal candidates for cellular immunotherapy in the treatment of cancer. Thereby, the cytotoxicity of NK cells is regulated by signals on both, the NK cells as well as the targeted tumor cells, and the interplay and balance of these signals determine the killing capacity of NK cells. One promising avenue in cancer treatment is therefore the combination of NK cell therapy with agents that either help to increase the killing capacity of NK cells or sensitize tumor cells to an NK cell-mediated attack. In this mini-review, we present different strategies that can be explored to unleash the potential of NK cell immunotherapy. In particular, we summarize how modulation of apoptosis signaling within tumor cells can be exploited to sensitize tumor cells to NK cellmediated cytotoxicity.
\end{abstract}

Keywords Immunotherapy $\cdot$ Natural killer cells $\cdot$ Apoptosis $\cdot$ Cancer

\section{NK cells for anticancer therapy}

Among the players of the innate immune system, NK cells represent potent effectors which kill stressed and abnormal cells such as transformed malignant cells. NK cells are lymphocytes identified by the expression of an isoform of the neural cell adhesion molecule CD56 and by the concomitant absence of the CD3 antigen. According to their functional properties, NK cells can be classified into different subpopulations forming two main subsets of cytotoxic

Meike Vogler

m.vogler@kinderkrebsstiftung-frankfurt.de

1 Institute for Experimental Cancer Research in Pediatrics, Goethe-University Frankfurt, Komturstrasse 3a, 60528 Frankfurt, Germany

2 Children's Hospital, Goethe-University Frankfurt, Frankfurt, Germany

3 Experimental Immunology, Goethe-University Frankfurt, Frankfurt, Germany

4 Department of Hematology, Medical Oncology, and Pulmonary Medicine, University Medical Center, Johannes Gutenberg-University, Mainz, Germany

5 Frankfurt Cancer Institute, Goethe-University Frankfurt, Frankfurt, Germany
$(\mathrm{CD} 56 \mathrm{dim} \mathrm{CD} 16+)$ and immunoregulatory $\left(\mathrm{CD} 56^{\mathrm{high}} \mathrm{CD}\right.$ $16^{\mathrm{dim} / \mathrm{neg}}$ ) NK cells (reviewed in [1]).

NK cells can distinguish tumor cells from normal cells by a balance of inhibitory and activating receptors. In brief, inhibitory receptors, such as the killer immunoglobulin-like receptors (KIR), recognize major histocompatibility complex (MHC) class I molecules which are highly expressed in normal cells and prevent immune attack. Conversely, tumor cells often down-modulate MHC class I expression which induces the engagement of activating receptors, such as natural cytotoxicity receptors (NCR) and NKG2D. These activating receptors recognize the absence of MHC class I molecules and bind to stress-induced molecules (i.e., MIC A/B, ULBP 1-2, RAE-1, hemagglutinin of influenza virus) expressed on the tumor cell surface [2]. Upon ligation of the activating receptors, the immunoregulatory NK cells release pro-inflammatory cytokines like interferon (IFN)- $\gamma$, whereas the cytotoxic NK cells directly attack the target cell [3].

Due to their intrinsic characteristics, NK cells represent a promising therapeutic option for cancer patients. The efficacy of NK cell-mediated immunotherapy depends on the optimization of the choice of the cell source, on the one hand, and of the induction of NK cell cytotoxicity, on the other hand [4]. The first clinically applied NK cells were autologous cells derived from the same patient. Due to limited tumor recognition, these showed an insufficient anti-cancer response in clinical trials 
[5]. The feasibility and safety of allogeneic NK cells, derived from peripheral blood, umbilical cord blood, or induced from human embryonic or pluripotent stem cells has been demonstrated for hematological and solid tumors [6-9]. Accordingly, allogeneic NK cells derived from a haploidentical donor can prevent leukemia relapse and improve the outcome following hematopoietic stem cell transplantation without concomitant graft versus host disease $[9,10]$. Also, in non-transplantation settings, adoptively transferred allogeneic NK cells can exert a cytotoxic effect against leukemic and tumor cells (graft versus tumor/leukemia effect) [11].

As an alternative to primary cells, the Food and Drug Administration (FDA)-approved NK cell line NK-92, which can be expanded to high numbers under good manufacturing practice conditions, can be used $[12,13]$. Despite the numerous advantages of using this cell line, such as the cells' constitutive activity caused by the lack of almost all inhibitory receptors, and their "off-the-shelf" availability, the in vivo proliferative capacity is limited due to the need of irradiation prior to transfer.

There are different strategies to improve NK cell cytotoxicity ex vivo which have been reviewed elsewhere [14], most prominently cytokine treatment (such as interleukin (IL)-15, IL-2 or IL-12/IL-15/IL-18) [15] or the use of feeder cell lines like K562, RPMI8866 or EBV-LCL, genetically altered to express different combinations of cytokines such as a membrane-bound form of IL-15 (mbIL-15), IL-21 or NK-stimulatory molecules like 4-1BB ligand or OX40 $[4,16-19]$. NK cells expanded in the presence of K562mbIL15-4-1BBL cells yielded an increased expansion up to 1000-fold compared to K562 feeder cells alone [19]. Furthermore, bi- or trispecific engagers can be used to provide close proximity for the formation of the immunological synapse by binding the target cell and NK cell simultaneously $[4,12,20]$. Currently, several immune cell engagers are being evaluated in clinical trials targeting amongst others CD30, CD33, or HER2 for the treatment of hematological and solid tumors (NCT03214666, NCT04101331, NCT01221571, NCT02665650, NCT04143711).

One limitation of NK cell-based immunotherapy is that tumor cells often escape the immune attack and develop resistance to apoptosis. Therefore, pharmaceuticals that may sensitize tumors to the NK cell-mediated immune attack are of high clinical relevance. To this end, several drugs or antibodies are currently being evaluated in clinical trials which are summarized in Table 1.

\section{Induction of apoptosis by NK cells}

Apoptosis can be initiated in the tumor cell via two separate but interconnected pathways (Fig. 1). Firstly, in the extrinsic pathway, the ligation of death receptors on the cell surface can result in the formation of the death-inducing signaling complex (DISC) and the activation of caspase- 8 as initiator caspase. Secondly, cellular stress can trigger the activation of the intrinsic or mitochondrial apoptosis pathway. Here, stress sensors signal to the B-cell lymphoma 2 (Bcl-2) proteins to trigger the release of mitochondrial cytochrome $\mathrm{c}$ into the cytosol. Once in the cytosol, cytochrome c facilitates the assembly of the apoptosome, in which the initiator caspase- 9 is activated. Both caspase- 8 and caspase- 9 can activate caspase- 3 , thus starting the caspase cascade and the biochemical and morphological characteristics of apoptosis [21].

The direct cytotoxicity of NK cells occurs upon formation of an immunological synapse linking the NK cell with the targeted tumor cell. Here, NK cells can release cytotoxic granule constituents including perforin and granzymes [22]. Granzymes are serine proteases that are specifically found in the cytotoxic granules of lymphocytes. Both granzyme A and granzyme B are expressed in NK cells, and upon perforin-mediated plasma membrane perforation, granzymes can enter the targeted cell to induce cell death by interacting with multiple players within the extrinsic and intrinsic apoptotic pathway.

Granzyme B has been shown to induce apoptosis by directly activating caspase-3, thereby initiating a mitochondrial amplification loop [23]. A similar study has determined that full activation of caspase- 3 by granzyme $B$ requires the release of pro-apoptotic factors from the mitochondria [24]. In addition, granzyme B can short-circuit the need for active caspase- 8 as an amplification signal between the extrinsic and the intrinsic apoptotic pathway by cleaving the BH3only protein BID to the active form tBID, thus directly promoting mitochondrial membrane permeabilization [25]. Further evidence indicating that mitochondria play an important role in granzyme B-mediated cell death has been provided by multiple studies showing that overexpression of the antiapoptotic protein $\mathrm{Bcl}-2$ can prevent granzyme-mediated cell death [24, 26, 27]. Of note, granzyme B can also circumvent the need for active caspases and cleave the nuclear caspase substrate Inhibitor of caspase-activated DNase (ICAD), thus releasing caspase-activated DNase (CAD) and inducing DNA fragmentation independently of caspases [28, 29].

In a separate mode of action, NK cells can also induce extrinsic apoptosis using ligands like Fas ligand (FasL) or tumor necrosis factor (TNF)-related apoptosis inducing ligand (TRAIL), which are either expressed on the surface or secreted as a shorter soluble protein, and which can engage death receptors on the tumor cells. Death receptors belong to the TNF protein family and once engaged, these receptors oligomerize to facilitate DISC assembly. Assembly of the DISC leads to activation of caspase- 8 as the apical caspase in the extrinsic apoptotic pathway. The two ways in which NK cells can kill tumor cells are not strictly separated, and in 
Table 1 List of clinical trials with adoptive NK cells investigated in combination with other therapeutics

\begin{tabular}{|c|c|c|c|c|c|c|}
\hline NCT number & NK cells & Combination & Malignancy & Phase & $\begin{array}{l}\text { First } \\
\text { posted } \\
\text { (Year) }\end{array}$ & Status \\
\hline NCT00376805 & Allogeneic NK cells & $\begin{array}{l}\text { Cyclophosphamide, } \\
\text { fludarabine }\end{array}$ & Breast cancer & 2 & 2006 & Terminated \\
\hline NCT00625729 & Donor NK cells & $\begin{array}{l}\text { Rituximab, fludarabine, } \\
\text { cyclophosphamide }\end{array}$ & $\begin{array}{l}\text { CLL, non-Hodgkin lym- } \\
\text { phoma }\end{array}$ & 1 & 2008 & Terminated \\
\hline NCT00698009 & Haploidentical NK cells & $\begin{array}{l}\text { Cyclophosphamide, } \\
\text { fludarabine }\end{array}$ & Neuroblastoma & 2 & 2008 & Terminated \\
\hline NCT00941928 & Haploidentical NK cells & Epratuzumab & ALL & 2 & 2009 & Terminated \\
\hline NCT01593670 & Donor NK cells & Decitabine, vorinostat & MDS & 2 & 2012 & Completed \\
\hline NCT02316964 & Donor NK cells & Decitabine & AML & 1 & 2014 & Completed \\
\hline NCT02370017 & $\begin{array}{l}\text { NK cell enriched lympho- } \\
\text { cytes (ANKL) }\end{array}$ & Docetaxel & Non-small cell lung cancer & 2 & 2015 & Unknown \\
\hline NCT02734524 & Autologous NK cells & Taxol, carboplatin & Non-small cell lung cancer & 2 & 2016 & Unknown \\
\hline NCT02843126 & NK cells & Trastuzumab & Breast cancer & 1 and 2 & 2016 & Completed \\
\hline NCT02843204 & Allogeneic NK cells & Pembrolizumab & Multiple cancers & 1 and 2 & 2016 & Completed \\
\hline NCT02845856 & NK cells & Cetuximab & Non-small cell lung cancer & 1 and 2 & 2016 & Completed \\
\hline NCT02857920 & Allogeneic NK cells & Bevacizumab & Multiple cancers & 1 and 2 & 2016 & Completed \\
\hline NCT03056339 & CD19 CAR-NK cells & $\begin{array}{l}\text { Fludarabine, cyclophos- } \\
\text { phamide }\end{array}$ & $\begin{array}{l}\text { ALL, CLL, non-Hodgkin } \\
\text { lymphoma }\end{array}$ & 1 and 2 & 2017 & Recruiting \\
\hline NCT03366064 & Haploidentical NK cells & Pemetrexed & Non-small cell lung cancer & 1 & 2017 & Completed \\
\hline NCT03554889 & Autologous NK cells & Nimotuzumab & Multiple cancers & 1 & 2018 & Unkown \\
\hline NCT03841110 & $\begin{array}{l}\text { Allogeneic NK cells } \\
\text { (FT500) }\end{array}$ & $\begin{array}{l}\text { Nivolumab, pembroli- } \\
\text { zumab, atezolizumab, } \\
\text { cyclophophamide, } \\
\text { fludarabine }\end{array}$ & Multiple cancers & 1 & 2019 & Recruiting \\
\hline NCT03937895 & Allogeneic NK cells & Pembrolizumab & Biliary tract cancer & 1 and 2 & 2019 & Recruiting \\
\hline NCT03941262 & $\begin{array}{l}\text { Autologous NK cells } \\
\text { (SKN01) }\end{array}$ & Avelumab, pembrolizumab & Multiple cancers & 1 & 2019 & Recruiting \\
\hline NCT03958097 & Autologous NK cells & PD-1/PD-L1 antibody & Non-small cell lung cancer & 2 & 2019 & Unknown \\
\hline NCT04220684 & Haploidentical NK cells & $\begin{array}{l}\text { Cytarabine, decitabine, } \\
\text { fludarabine }\end{array}$ & AML, MDS & 1 & 2020 & Recruiting \\
\hline NCT04290546 & Donor NK cells & Ipilimumab & Head and neck cancer & 1 & 2020 & Recruiting \\
\hline NCT04558931 & Autologous NK cells & Isatuximab & MM & 2 & 2020 & Not yet recruiting \\
\hline NCT04796675 & CD19 CAR-NK cells & $\begin{array}{l}\text { Fludarabine, cyclophos- } \\
\text { phamide }\end{array}$ & $\begin{array}{l}\text { ALL, CLL, non-Hodgkin } \\
\text { lymphoma }\end{array}$ & 1 & 2021 & Recruiting \\
\hline NCT04847466 & $\begin{array}{l}\text { Irradiated PD-L1 CAR-NK } \\
\text { cells }\end{array}$ & Pembrolizumab & $\begin{array}{l}\text { Gastric or head and neck } \\
\text { cancer }\end{array}$ & 2 & 2021 & Not yet recruiting \\
\hline NCT04872634 & $\begin{array}{l}\text { Autologous NK cells } \\
\text { (SKN01) }\end{array}$ & Gemcitabine, cetuximab & Non-small cell lung cancer & 1 and 2 & 2021 & Not yet recruiting \\
\hline
\end{tabular}

serial killing NK cells can switch from granzyme B-mediated killing to death receptor-mediated cytotoxicity [30].

\section{Sensitizing tumor cells to NK cell-mediated attack}

Given that NK cells trigger apoptosis, alterations within the tumor cell that confer resistance to apoptosis may also build up a resistance to NK cell-mediated killing and allow immune escape. This however also implies that therapeutic strategies aiming to restore apoptosis sensitivity in cancer cells may be beneficial for NK cell-based immunotherapy. Hence, several molecularly targeted strategies may be applicable in combination with NK cells (Fig. 1).

\section{Smac mimetics}

One of the mechanisms by which cancer cells acquire apoptosis resistance involves the inhibitor of apoptosis proteins (IAPs). Several IAPs are frequently overexpressed in cancer [31]. They function by inhibiting caspases in 


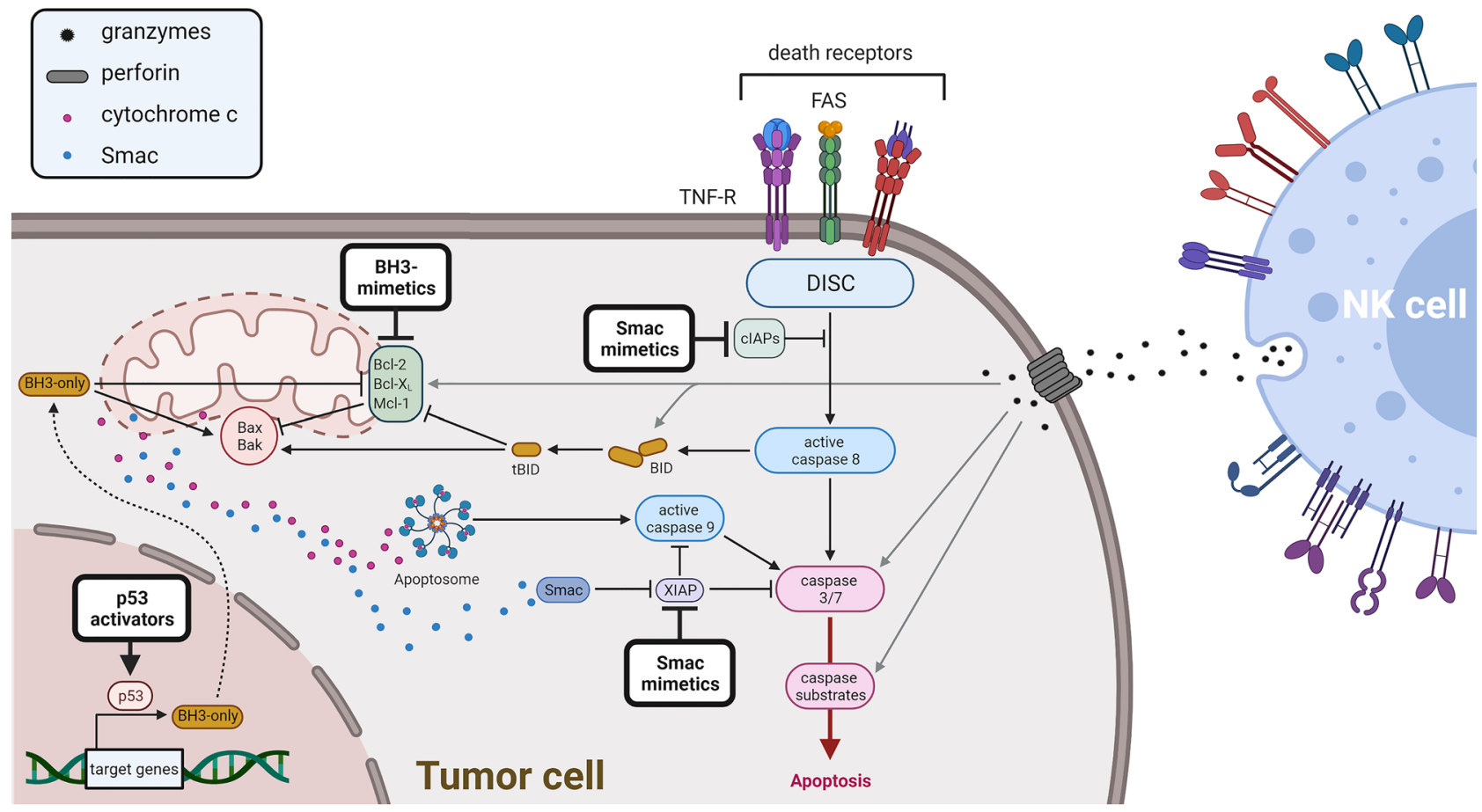

Fig. 1 Proapoptotic therapeutics may potentiate NK cell-mediated cytotoxicity. Apoptosis can be initiated either at the mitochondria (intrinsic apoptosis) or upon ligation of death receptors on the plasma membrane (extrinsic apoptosis). This results in apoptosis signaling illustrated using black arrows. Apoptosis can be modulated using

both the extrinsic and intrinsic apoptotic pathway. Their endogenous counter player is the mitochondrial protein second mitochondria-derived activator of caspases (Smac). Once the outer mitochondrial membrane is permeabilized during apoptosis, Smac is being released into the cytosol alongside of cytochrome c, and can inhibit IAPs, thus facilitating caspase activation. A first indication that the modulation of the balance between IAPs and Smac may increase the effects of immunotherapy has been obtained by overexpression of Smac in melanoma cells, which increased their sensitivity to granzyme B- or killer lymphocyte-mediated cytotoxicity [32]. As a therapeutic approach in cancer, apoptosis can be induced using small-molecule IAP inhibitors or Smac mimetics. We have recently shown that the Smac mimetic BV6 can improve NK cell-mediated killing of rhabdomyosarcoma cells, thus providing a proof-of-principle showing that an interference with the apoptotic regulation within the tumor cells can synergize with NK cell therapy [33]. Previously, Hodgkin lymphoma cell lines could be sensitized toward an NK cell-mediated killing by Smac mimetic treatment [34]. In a similar study, the Smac mimetic APG-1387 has been shown to increase NK cell-mediated killing of hepatocellular cancer in vitro and in vivo, indicating that this combination may be applicable and beneficial in a broad (a) Smac mimetics, (b) BH3 mimetics, (c) activators of p53, or (d) TRAIL agonists, thus overcoming apoptosis blockades within the tumor cell and facilitating NK cell-mediated attack, illustrated using gray arrows

range of malignancies, possibly particularly in combination with immune-checkpoint inhibitors [35, 36].

\section{BH3 mimetics}

By regulating the release of mitochondrial cytochrome c, the Bcl-2 proteins play a key role in the induction of apoptosis [37]. The Bcl-2 protein family contains antiapoptotic members, including Bcl-2, Bcl- $\mathrm{X}_{\mathrm{L}}$, and Mcl-1, as well as proapoptotic proteins. Among the proapoptotic Bcl-2 proteins, there are the pore-forming proteins $\mathrm{Bax}$ and $\mathrm{Bak}$, which are activated during apoptosis and facilitate the loss of mitochondrial membrane potential by integrating into the outer mitochondrial membrane. The other group of proapoptotic $\mathrm{Bcl}-2$ proteins are the $\mathrm{Bcl}-2$ homology domain 3 (BH3)-only proteins, which function as sensors for cellular stress and promote the activation of Bax and Bak. The antiapoptotic Bcl-2 proteins are frequently overexpressed in cancer and prevent apoptosis by blocking the activity of the proapoptotic Bcl-2 family members. Based on the nature of the interactions within the Bcl-2 protein family, the antiapoptotic $\mathrm{Bcl}-2$ proteins serve as promising targets for the development of novel anticancer drugs [38-40]. With venetoclax/ABT-199, the first of these BH3-mimetics targeting $\mathrm{Bcl}-2$ has been approved for the treatment of leukemia, 
highlighting the potential of the $\mathrm{Bcl}-2$ proteins as targets in anticancer therapy [41]. Of note, in chronic lymphocytic leukemia (CLL), venetoclax is commonly administered to patients in combination with the anti-CD20 antibody rituximab, which increases antibody-dependent cellular cytotoxicity (ADCC) and improves the outcome compared to single treatment $[42,43]$. Given that multiple studies have shown increased NK cell activation and cytotoxicity upon administration of rituximab [44-46], it is interesting to speculate that the combination of venetoclax with rituximab and NK cell immunotherapy may be advantageous in the treatment of cancer, in particular in B-cell malignancies. In support of the idea that targeting antiapoptotic $\mathrm{Bcl}-2$ proteins with BH3 mimetics may increase NK cell-mediated cytotoxicity, a recent report has described that inhibition of Mcl-1, but not Bcl-2, increased the therapeutic efficiency of NK cells against acute myeloid leukemia (AML) cells [47].

\section{Activators of $\mathrm{p} 53$}

The importance of the tumor suppressor gene TP53 and its protein p53 in cancer has been reviewed extensively [47, 48]. Restoring the function of p53 is a well-studied avenue in cancer research, and several strategies to restore functional p53 in tumor cells have been identified [49]. Whereas some strategies involve the delivery of p53 in nanocomplexes, the small compound Nutlin-3a antagonizes the inhibitory interaction of MDM2 with p53, thus rescuing p53 function, albeit only in cells expressing wild-type p53. Among the many target genes of $\mathrm{p} 53$, there are several genes relevant for the induction of apoptosis, e.g., the BH3-only proteins Puma and Noxa, highlighting the potential of p53 restoration in the sensitization towards apoptotic stimuli. A recent study has shown that Nutlin-3a can increase surface expression of NKG2D ligands on neuroblastoma cells which coincides with increased cytotoxic activity of NK cells and reduced neuroblastoma growth in vivo, thus identifying a direct link between p53 function and NK cell activity [50]. Further support for a direct link between p53 and expression of NKG2D ligands has been provided by an earlier study showing p53-dependent expression of ULBP1/2 in cancer cells [51].

\section{Increasing the killing capacity of NK cells by modulation of the immune system}

As an alternative strategy, instead of sensitizing the tumor cells, the killing capacity of NK cells can be increased to facilitate better tumor cell killing. This can be achieved by modulation of the immune system using either immunomodulatory drugs (IMiDs) or immune checkpoint blockade (ICB) (Fig. 2).

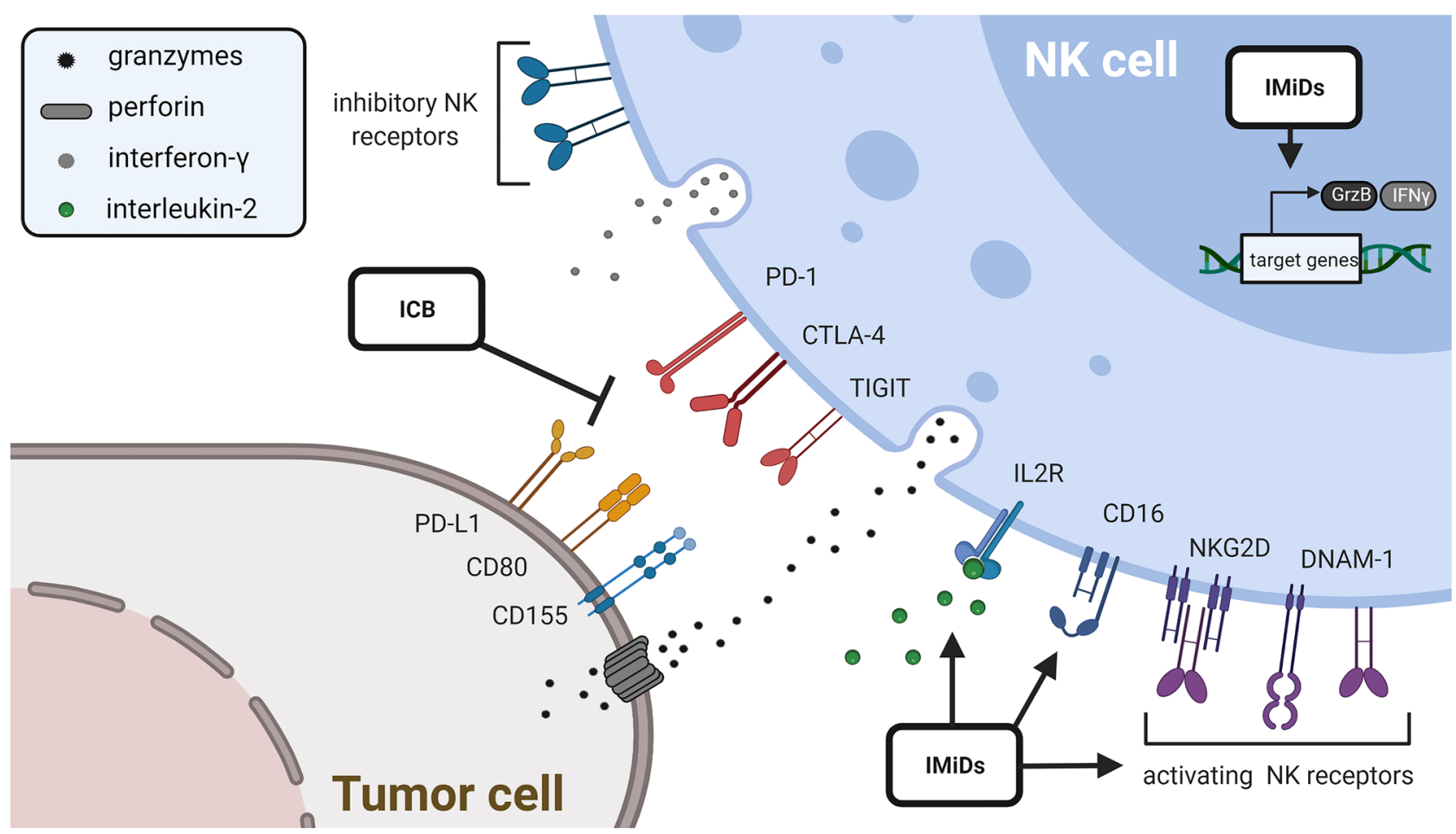

Fig. 2 Modulation of the immune system using either IMiDs or ICB 


\section{Effect of immunomodulatory drugs on the cytotoxicity of NK cells}

The IMiDs thalidomide, lenalidomide, and pomalidomide have demonstrated antiangiogenic, immunomodulatory, and antiproliferative effects and are used especially for the treatment of multiple myeloma (MM) and myelodysplastic syndrome (MDS) with 5q deletion. In recent years, substantial progress toward discovering the mechanisms of action for IMiDs has been achieved. To this end, the cereblon receptor has been identified as a direct binding target of IMiDs. By binding to cereblon, an E3 ubiquitin ligase complex is formed leading to the selective degradation of transcription factors IKZF1 and IKZF2 in MM cells and CD1alpha in MDS with $5 q$ deletion [79-81]. The discovery that IMiDs do not only bind to cereblon but also to the zeta-chain-associated protein kinase-70 (Zap-70) in T-cells and NK cells has provided further explanation of the enhanced antitumor toxicity of NK cells upon treatment with IMiDs [82].

The enhanced NK cell cytotoxicity upon administration of IMiDs can be attributed to indirect and direct effects on NK cells. Indirect effects include the increased IL-2 production of T-cells leading to an increase in NK cell cytotoxicity and ADCC in MM cells [83]. The elevated levels of IL-2 and the activation of NK cells are associated with the upregulation of CD69 on NK cells and increased IFN- $\gamma$ synthesis [84]. In a severe combined immunodeficient (SCID) mouse model where T-cell function is impaired, the activation and recruitment of NK cells to tumor sites under treatment with lenalidomide seemed to be related to dendritic cells and their secreted cytokines [85]. Increased NK cell recognition and killing of MM cells has been reported by the indirect effect of increased expression of MICA and PVR/CD155 on MM cells which bind to the activating receptors NKG2D and DNAM-1 on NK cells [86]. For pomalidomide, an increase of the MHC class I expression on AML cells has been observed [87].

Direct activation of NK cell-mediated antitumor activity has been shown for lenalidomide, which increases expression of CD16, CD40L, and LFA1 on NK cells and thereby promotes ADCC [88]. In addition, upregulation of CD56 and downregulation of NKp30, NKp46, and KIR2D have been observed [87]. Moreover, IMiDs downregulate the suppressor of cytokine signaling 1 (SOCS1) in NK, NKT-, and T-cells [89]. An increased proportion of stimulated NK cells producing IFN- $\gamma$ and a higher amount of IFN- $\gamma$ produced per NK cell have been observed upon treatment with lenalidomide [90]. IMiDs can also enhance NK cell cytotoxicity via increased granzyme-B expression, which has been shown as a new direct effect on NK cells for pomalidomide and lenalidomide in a cereblon-mediated Zap-70-independent as well as a Zap-70-mediated cereblon-independent pathway [82]. It has further been reported that lenalidomide augments rearrangements in cortical actin at the immunological synapse of activated NK cells [90]. On the tumor side, IMiDs increase the polarization of lytic granules of AML cells in the NK cell immunological synapse [91].

Overall, the effects of IMiDs on NK cells have also been investigated in several clinical trials. Interestingly, MM patients with relapse treated with lenalidomide showed increased numbers of $\mathrm{NKp}_{4} 4^{+} \mathrm{NK}$ cells [92]. Under treatment with lenalidomide, patients with mantle cell lymphoma showed elevated levels of NK cells in relation to total lymphocyte counts [93]. To date, there are several other thalidomide analogues under development which show a higher affinity to cereblon, and the ongoing clinical trials will shed light on the effects of these new IMiDs on NK cell cytotoxicity and evaluate the most promising routes for combination treatments.

\section{Interactions between immune checkpoint blockade and NK cell therapy}

In recent years, in particular, the field of immunomodulation with checkpoint inhibitors got international and interdisciplinary attention, which resulted in the award of the Nobel Prize to James P Allison and Tasuku Honjo in 2018. NK cells, still a niche within immunotherapy, also express immune checkpoint proteins, enabling the possibility for therapeutic intervention and enhancing NK cell-mediated cytotoxicity using ICB (summarized in Table 1).

\section{PD-1/PD-L1 blockade}

Programmed cell death protein-1 (PD-1) is expressed on immune cells such as NK cells and other immune cells like activated T-cells, B-cells, and dendritic cells, whereas its ligand programmed death ligand 1 (PD-L1) is expressed on several types of tumor cells [94]. A high expression of PD-1 is found on NK cells in the peripheral blood, and the expression of PD-1 on NK cells is upregulated in cancer patients (summarized in [95]). Activated NK cells express PD-1 and, if it is engaged by PD-L1 expressed on the tumor cells, the NK cell-mediated tumor attack is suppressed. Consequently, PD-L1 expression in cancer cells resulted in reduced NK cell responses and generation of more aggressive tumors in vivo. Therefore, ICB is a promising therapy and blocking of the PD-1/PD-L1 axis caused a strong NK cell response in several mouse models of cancer which was indispensable for an efficient anti-cancer effect of ICB therapy [96].

In support of this, a recent study identified a synergistic NK cell-mediated cytotoxic effect together with anti PD-L1 treatment. Patient-derived ex vivo expanded NK cells successfully killed lung cancer cells, secreted IFN- $\gamma$ thus reactivating immunosuppressed tumor infiltrated lymphocytes 
and increased PD-L1 expression on tumor cells, leading to a change in anti-PD-L1 response and an anti-PD-L1 second-hit strategy [97]. In triple-negative breast cancer, the anti-PD-L1-antibody avelumab triggered NK cellmediated cytotoxicity and cytokine production. Avelumab significantly improved NK cell-mediated cytotoxicity against triple-negative breast cancer cells and tumor cells expressing higher levels of PD-L1 were shown to be more sensitive to avelumab-mediated ADCC. Also the stimulation of NK cells with IL-2 and IL-15 enhanced avelumabtriggered cytokine production and degranulation leading to an increased lytic activity against cancer cells [98].

First clinical evidence for a synergistic interaction between NK cells and ICB therapy has been provided by Lin and colleagues who showed in a clinical study that patients with advanced non-small cell lung cancer treated with pembrolizumab and allogenic NK cells had a longer median overall survival when compared with patients treated only with pembrolizumab (15.5 months vs. 13.3 months) [99].

To further increase the efficiency of ICB therapy, bispecific antibodies are currently being developed. To this end, enhanced efficacy in high-grade serous ovarian cancer has been shown for the bispecific antibody LY3434172, which simultaneously binds to PD-1 and PD-L1. LY3434172 has shown antitumor efficacy in vivo in humanized ovarian and other tumor xenograft mouse models. Of note, this bispecific antibody transits NK cells from inert to a more active and cytotoxic phenotype characterized by increased Myc and granzyme expression [100]. Even though monospecific ICB therapy has shown some clinical success, bispecific antiPD-1/PD-L1-antibodies like LY3434172 are anticipated to be more effective thanks to their ability to engage two different receptors in the vicinity [101].

\section{Other checkpoint inhibitors}

Apart from the classical PD-1/PD-L1 axis, NK cells express a broad variety of additional immune checkpoints. Cytotoxic T-lymphocyte-antigen 4 (CTLA-4), inhibiting the co-stimulatory signal of CD28, is a major target for ICB therapy. Inhibition of CTLA-4 using ipilimumab or tremelimumab successfully increased survival in melanoma patients $[102,103]$. Compared to T-cells, the functional role of CTLA-4 in NK cells is not yet well understood. It has been shown that ipilimumab markedly increased killing and secretion of IL-2 and IFN- $\gamma$ in NK cells [104]. In a more indirect manner, CTLA-4 targeting could deplete regulatory T-cells within the tumor site in a non-small cell lung cancer in vivo model, by that increasing the cytotoxic functionality of tumor-resident NK cells [105].

Recently, Deuse and colleagues have reported the SIRP $\alpha-C D 47$ axis, important in macrophage clearance and maturation of dendritic cells, as an inhibitory axis of
NK cells. This inhibitory effect is dependent on a CD47 expression threshold on the target cells, orchestrating the killing kinetic. Furthermore, antibody-mediated blocking of CD47 on target cells could markedly increase cytotoxic effector function [106]. T-cell immunoreceptor with Ig and ITIM domains (TIGIT) as an additional inhibitory receptor expressed on $\mathrm{T}$ - and NK cells is getting more attention as a target for possible ICB therapy. Blockage of TIGIT by a novel antibody led to an increased NK cell-mediated cytotoxicity in an in vivo lung adenocarcinoma model [107]. A complementary approach is the reduction of CD155/PVR, the ligand of TIGIT. Treatment of lung adenocarcinoma cells with the natural product rediocide-A could decrease the expression of CD155/PVR and increase NK cell-mediated anti-tumor cytotoxicity [108]. Taken together, the combination of ICB therapy with allogenic NK cells may elicit increased anti-tumor activity and thus represents a promising new therapeutic approach which is currently being investigated in several early-phase clinical trials (Table 1).

\section{Modulating both NK cells and tumor cells}

Several approaches have been identified that affect both NK cells and tumor cells, and thereby offer the opportunity to promote tumor cell killing from both sides. Here, we summarize the effects of hypomethylating agents (HMAs), TRAIL agonists, as well as kinase inhibitors (Fig. 3).

\section{Hypomethylating agents}

As chromatin regulators are among the most commonly mutated genes in various human cancers and as epigenetic dysregulation has been implicated as an important mechanism of oncogenesis [59], drugs targeting epigenetic mechanisms have been introduced into clinical practice as promising cancer therapeutics (reviewed in [60]). One important example are first-generation epigenetic drugs such as the nonselective HMAs azacitidine and decitabine that are approved therapeutics for the treatment of high-risk MDS and AML [61]. While HMAs have been successfully combined with various immunotherapeutic approaches, these agents have been implicated as promising combination partners for NK cell adoptive transfer (reviewed in [62]). Recent preclinical studies demonstrated that low-dose HMA treatment did not impair viability, proliferation, or killing efficiency of NK cells but may cooperate with NK cells against AML by upregulating NKG2D- and DNAM-1-activating ligands in the malignant cells [63]. The upregulation of NKG2D by HMAs has recently been confirmed in one clinical trial [64]. In NK cells, decitabine has been reported to induce (re-)expression of TRAIL, perforin, and KIR receptors that are commonly silenced by promotor hypermethylation in these cells [63, 


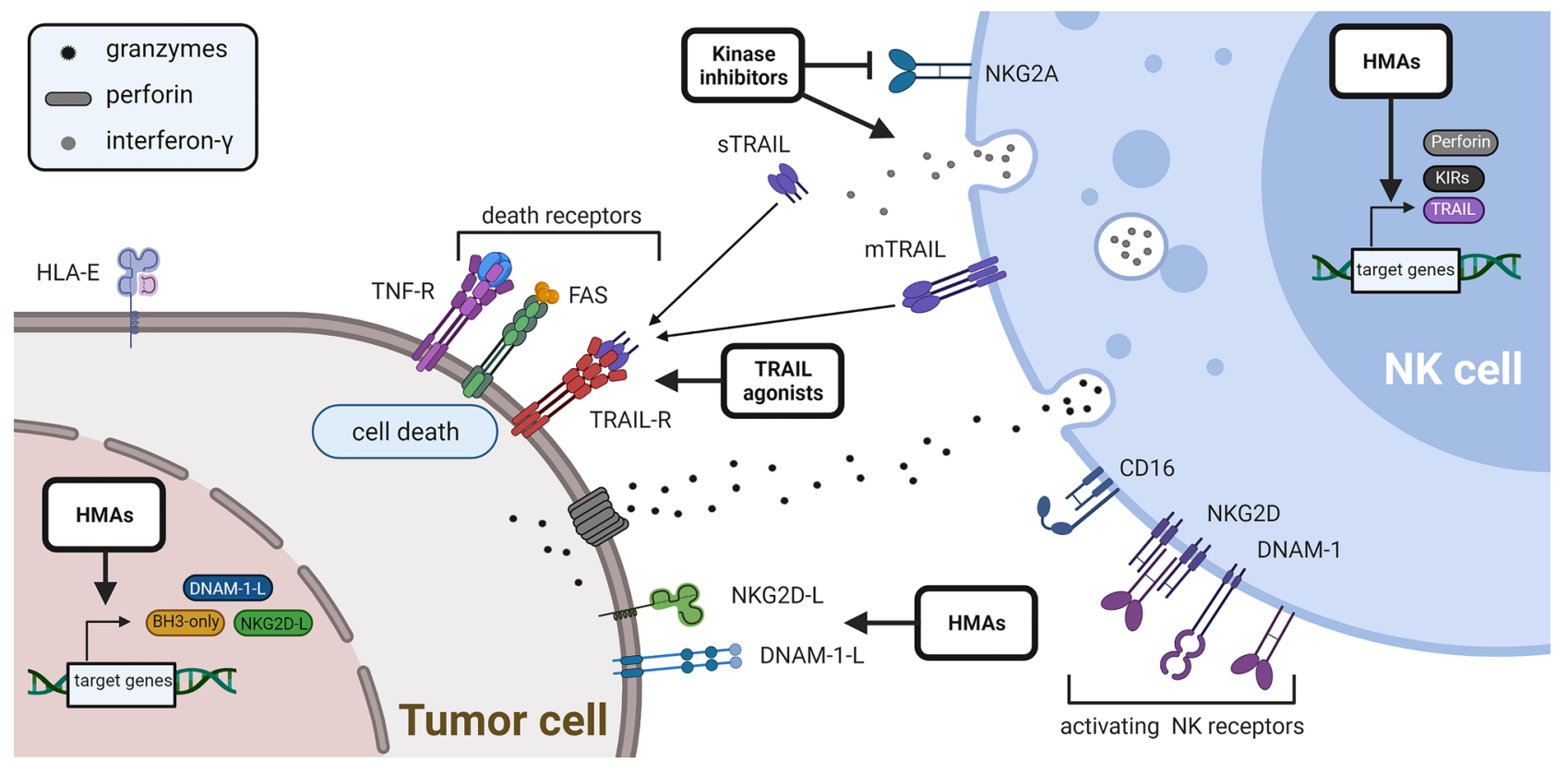

Fig. 3 Effects of HMAs, TRAIL agonists, as well as kinase inhibitors

65]. It is interesting to note, that sensitization of AML cells to NK cell-mediated killing has been associated with the use of decitabine, whereas other studies reported that azacitidine exposure impaired NK cytotoxicity against AML cells [63, $66,67]$. While the definitive reasons for these heterogeneous results remain obscure, substantial differences in drug concentrations may explain at least some of the differences between these studies. Further insights will probably be provided by clinical trials (see also Table 1) that are currently assessing various therapeutic NK cell products in combination with HMAs for the treatment of AML (NCT02316964, NCT04220684).

Future studies will also explore a potential synergism between NK cell-based cancer immunotherapy and the large number of established and emerging second-generation epigenetic drugs that target specific chromatin modifications in selected cancer types [60].

\section{TRAIL agonists}

TRAIL expression on the surface of cytotoxic NK cells is induced upon activation, e.g., by IL-2 or IL-15 [52]. Since its apoptosis-inducing receptors DR4 and DR5 are rarely expressed on healthy cells but frequently overexpressed on cancer cells, TRAIL-based therapies may be highly effective against cancer cells while sparing healthy cells [53]. Therefore, several strategies have been developed to trigger TRAILinduced apoptosis, including the use of recombinant soluble TRAIL, agonistic DR4 or DR5 antibodies, or gene therapy approaches (reviewed in [54]). Despite promising results in preclinical research, the early clinical trials with both agonistic TRAIL receptor antibodies as well as recombinant TRAIL have been disappointing, probably due to suboptimal agonistic activity of the selected compounds and the occurrence of resistance mechanisms within cancer cells [55]. Currently, a new generation of TRAIL-based compounds that achieve high-order clustering and better agonistic activity are entering clinical trials, thus offering new hope for this approach [53]. Of note, some studies indicate that a combination of recombinant TRAIL together with an agonistic DR5 antibody induced higher-order clustering of the TRAIL receptor and thus increased proapoptotic effects [56, 57]. Given that TRAIL is expressed on NK cells, it may therefore be highly feasible to combine a DR5 agonistic antibody with NK cell immunotherapy. This has been shown in ovarian cancer, where the combination of the DR5 agonistic antibody AD510 sensitizes apoptosis-resistant cells to an NK cell-mediated killing in xenograft models, thus supporting the hypothesis that NK cell-mediated immunosurveillance may be relying on functional TRAIL signaling [57]. In neuroblastoma, expression of DR5 correlated with apoptosis induced by activated NK cells, and a TRAIL-blocking antibody reduced NK cytotoxicity in 14 out of 17 cell lines tested, demonstrating that TRAIL signaling contributed to NK cell-mediated killing. Notably, only membrane-bound TRAIL alone was responsible for apoptosis induction, whereas soluble secreted TRAIL did not contribute [58]. Taken together, these studies indicate that in particular the use of agonistic DR5 antibodies may overcome apoptosis resistance and synergize with TRAILmediated killing by NK cells. 


\section{Immunomodulatory activity of kinase inhibitors}

The inhibition of aberrant growth factor signaling using kinase inhibitors is a promising avenue to limit tumor growth and induce apoptosis, and therefore, several compounds are successfully being applied in the treatment of cancer. In addition to the direct effect on tumor cells, kinase inhibitors may also exhibit immunomodulatory abilities (reviewed in [68]). In chronic myeloid leukemia (CML), treatment with the tyrosine kinase inhibitor dasatinib increased NK proliferation and cytotoxicity [69-71]. Of note, long-lasting and complete responses after treatment of CML patients with dasatinib or imatinib are significantly associated with high NK cell proliferation in the blood [72, 73]. Mechanistically, dasatinib has been shown to reduce the expression of NKG2A on cells isolated from CML patients by inhibiting p38 mitogen-activated protein kinase (MAPK), thus altering the balance between inhibitory and activating receptors and increasing NK cell cytotoxicity [69]. In addition, gene polymorphisms of NKG2D were found to be associated with disease control by dasatinib [74].

Besides leukemia, kinase inhibitors have been shown to modulate immune responses in solid tumors. For example, MAPK and cyclin-dependent kinase 4/6 inhibitors act in concert to suppress the proliferation of KRAS-mutant lung cancer cells by triggering the accumulation of NK cells within the tumor and promoting NK cell-dependent tumor cell killing [75]. Also, the anti-tumor effects of the protein kinase inhibitor sorafenib have been linked with NK cellmediated cytotoxicity. Accordingly, sorafenib can directly activate NK effector functions [76, 77] or induce a proinflammatory response in macrophages, which activates cytotoxic NK cells to attack hepatocellular cancer cells [78].

\section{Conclusion and outlook}

Several approaches have demonstrated that the sensitization of tumor cells toward proapoptotic stimuli can improve NK cell-mediated tumor attack. However, it remains to be discovered which of these approaches will deliver clinical benefit and achieve long-lasting tumor remission without toxic side effects. Most likely, this will not be achieved by a "one type fits all" strategy but will have to be tailored to the tumor type and individual cancer characteristics. To further improve NK cell-based immunotherapy, it may also be an option to increase the killing capacity of ex vivo expanded NK cells. To this end, more efficient activation protocols have recently been established, such as the synergistic stimulation with IL-15 and IL-21 [109], and may be further developed. Alternatively, genetic engineering may be applied to artificially improve NK cell cytotoxicity, ideally specifically targeted against tumor cells (reviewed in [12]). This has been demonstrated using chimeric antigen receptor (CAR)-expressing NK cells (CAR-NK cells) (reviewed in [1]). Currently, most approaches are based on well-established targets adapted from CAR-T cells, including CD19 and CD22, and CAR-NK cells against these targets are being investigated in clinical trials for hematological malignancies (reviewed in [110]). In addition, early clinical trials are ongoing evaluating NKG2D ligands and several common tumor antigens as CARs expressed on NK cells (reviewed in [111]). These approaches may unleash the full potential of NK cells as immunotherapy, and results of the clinical studies are highly anticipated. In the future, combinations of apoptosis-sensitizing agents with CAR-NK cells specifically designed to target the individual tumor may be foreseeable and hold great potential to place NK cell immunotherapy at the frontline of cancer immunotherapy.

Acknowledgements We apologize to all investigators whose work has not been cited in this article due to space limitations. We thank $\mathrm{C}$. Hugenberg for expert secretarial assistance. All illustrated figures have been created with BioRender.com (accessed in May 2021).

Author contribution MV and EU had the idea for this review; MV, SS, VS, LMR, VG, LB, and MK performed literature search and data analysis; and MV, VS, LMR, VG, SS, LB, MK, and EU drafted and critically revised the work.

Funding Open Access funding enabled and organized by Projekt DEAL. This work has been supported by the Deutsche Forschungsgemeinschaft DFG (CRC 1292 / IRTG).

\section{Declarations}

Conflict of interest The authors declare no competing interests.

Open Access This article is licensed under a Creative Commons Attribution 4.0 International License, which permits use, sharing, adaptation, distribution and reproduction in any medium or format, as long as you give appropriate credit to the original author(s) and the source, provide a link to the Creative Commons licence, and indicate if changes were made. The images or other third party material in this article are included in the article's Creative Commons licence, unless indicated otherwise in a credit line to the material. If material is not included in the article's Creative Commons licence and your intended use is not permitted by statutory regulation or exceeds the permitted use, you will need to obtain permission directly from the copyright holder. To view a copy of this licence, visit http://creativecommons.org/licenses/by/4.0/.

\section{References}

1. Wendel P, Reindl LM, Bexte T, Kunnemeyer L, Sarchen V, Albinger N, Mackensen A, Rettinger E, Bopp T, Ullrich E (2021) Arming immune cells for battle: a brief journey through the advancements of $\mathrm{T}$ and NK Cell Immunotherapy. Cancers (Basel) 13. https://doi.org/10.3390/cancers13061481

2. Ullrich E, Koch J, Cerwenka A, Steinle A (2013) New prospects on the NKG2D/NKG2DL system for oncology. Oncoimmunology 2:e26097. https://doi.org/10.4161/onci.26097 
3. Jacobs B, Ullrich E (2012) The interaction of NK cells and dendritic cells in the tumor environment: how to enforce NK cell \& DC action under immunosuppressive conditions? Curr Med Chem 19:1771-1779. https://doi.org/10.2174/092986712800099857

4. Myers JA, Miller JS (2021) Exploring the NK cell platform for cancer immunotherapy. Nat Rev Clin Oncol 18:85-100. https:// doi.org/10.1038/s41571-020-0426-7

5. Parkhurst MR, Riley JP, Dudley ME, Rosenberg SA (2011) Adoptive transfer of autologous natural killer cells leads to high levels of circulating natural killer cells but does not mediate tumor regression. Clin Cancer Res 17:6287-6297. https://doi. org/10.1158/1078-0432.CCR-11-1347

6. Shaffer BC, Le Luduec JB, Forlenza C, Jakubowski AA, Perales MA, Young JW, Hsu KC (2016) Phase II study of haploidentical natural killer cell infusion for treatment of relapsed or persistent myeloid malignancies following allogeneic hematopoietic cell transplantation. Biol Blood Marrow Transplant 22:705-709. https://doi.org/10.1016/j.bbmt.2015.12.028

7. Spanholtz J, Preijers F, Tordoir M, Trilsbeek C, Paardekooper J, de Witte T, Schaap N, Dolstra H (2011) Clinical-grade generation of active NK cells from cord blood hematopoietic progenitor cells for immunotherapy using a closed-system culture process. PLoS One 6:e20740. https://doi.org/10.1371/journal.pone.0020740

8. Rubnitz JE, Inaba H, Ribeiro RC, Pounds S, Rooney B, Bell T, Pui CH, Leung W (2010) NKAML: a pilot study to determine the safety and feasibility of haploidentical natural killer cell transplantation in childhood acute myeloid leukemia. J Clin Oncol : Official J Am Soc Clin Oncol 28:955-959. https://doi.org/10. 1200/JCO.2009.24.4590

9. Ruggeri L, Capanni M, Urbani E, Perruccio K, Shlomchik WD, Tosti A, Posati S, Rogaia D, Frassoni F, Aversa F et al (2002) Effectiveness of donor natural killer cell alloreactivity in mismatched hematopoietic transplants. Science 295:2097-2100. https://doi.org/10.1126/science. 1068440

10. Perez-Martinez A, de Prada VI, Fernandez L, Gonzalez-Vicent M, Valentin J, Martin R, Maxwell H, Sevilla J, Vicario JL, Diaz MA (2012) Natural killer cells can exert a graft-vs-tumor effect in haploidentical stem cell transplantation for pediatric solid tumors. Exp Hematol 40(882-891):e881. https://doi.org/10. 1016/j.exphem.2012.07.004

11. Miller JS, Soignier Y, Panoskaltsis-Mortari A, McNearney SA, Yun GH, Fautsch SK, McKenna D, Le C, Defor TE, Burns LJ et al (2005) Successful adoptive transfer and in vivo expansion of human haploidentical NK cells in patients with cancer. Blood 105:3051-3057. https://doi.org/10.1182/blood-2004-07-2974

12. Reindl LM, Albinger N, Bexte T, Muller S, Hartmann J, Ullrich E (2020) Immunotherapy with NK cells: recent developments in gene modification open up new avenues. Oncoimmunology 9:1777651. https://doi.org/10.1080/2162402X.2020.1777651

13. Tonn T, Becker S, Esser R, Schwabe D, Seifried E (2001) Cellular immunotherapy of malignancies using the clonal natural killer cell line NK-92. J Hematother Stem Cell Res 10:535-544. https://doi.org/10.1089/15258160152509145

14. Granzin M, Wagner J, Kohl U, Cerwenka A, Huppert V, Ullrich E (2017) Shaping of natural killer cell antitumor activity by ex vivo cultivation. Front Immunol 8:458. https://doi.org/10.3389/fimmu. 2017.00458

15. Romee R, Rosario M, Berrien-Elliott MM, Wagner JA, Jewell BA, Schappe T, Leong JW, Abdel-Latif S, Schneider SE, Willey $\mathrm{S}$ et al (2016) Cytokine-induced memory-like natural killer cells exhibit enhanced responses against myeloid leukemia. Sci Transl Med 8: 357ra123. https://doi.org/10.1126/scitranslmed.aaf2341

16. Kweon S, Phan MT, Chun S, Yu H, Kim J, Kim S, Lee J, Ali AK, Lee SH, Kim SK et al (2019) Expansion of human NK cells using K562 cells expressing OX40 ligand and short exposure to
IL-21. Front Immunol 10:879. https://doi.org/10.3389/fimmu. 2019.00879

17. Denman CJ, Senyukov VV, Somanchi SS, Phatarpekar PV, Kopp LM, Johnson JL, Singh H, Hurton L, Maiti SN, Huls MH et al (2012) Membrane-bound IL-21 promotes sustained ex vivo proliferation of human natural killer cells. PLoS One 7:e30264. https://doi.org/10.1371/journal.pone.0030264

18. Fujisaki H, Kakuda H, Shimasaki N, Imai C, Ma J, Lockey T, Eldridge P, Leung WH, Campana D (2009) Expansion of highly cytotoxic human natural killer cells for cancer cell therapy. Cancer Res 69:4010-4017. https://doi.org/10.1158/0008-5472. CAN-08-3712

19. Imai C, Iwamoto S, Campana D (2005) Genetic modification of primary natural killer cells overcomes inhibitory signals and induces specific killing of leukemic cells. Blood 106:376-383. https://doi.org/10.1182/blood-2004-12-4797

20. Gauthier L, Morel A, Anceriz N, Rossi B, Blanchard-Alvarez A, Grondin G, Trichard S, Cesari C, Sapet M, Bosco F et al (2019) Multifunctional natural killer cell engagers targeting NKp46 trigger protective tumor immunity. Cell 177:701-1713 e1716. https://doi.org/10.1016/j.cell.2019.04.041

21. Fulda S, Debatin KM (2006) Extrinsic versus intrinsic apoptosis pathways in anticancer chemotherapy. Oncogene 25:4798-4811. https://doi.org/10.1038/sj.onc.1209608

22. Voskoboinik I, Whisstock JC, Trapani JA (2015) Perforin and granzymes: function, dysfunction and human pathology. Nat Rev Immunol 15:388-400. https://doi.org/10.1038/nri3839

23. Metkar SS, Wang B, Ebbs ML, Kim JH, Lee YJ, Raja SM, Froelich CJ (2003) Granzyme B activates procaspase-3 which signals a mitochondrial amplification loop for maximal apoptosis. J Cell Biol 160:875-885. https://doi.org/10.1083/jcb. 200210158

24. Sutton VR, Wowk ME, Cancilla M, Trapani JA (2003) Caspase activation by granzyme B is indirect, and caspase autoprocessing requires the release of proapoptotic mitochondrial factors. Immunity 18:319-329. https://doi.org/10.1016/s1074-7613(03)00050-5

25. Barry M, Heibein JA, Pinkoski MJ, Lee SF, Moyer RW, Green DR, Bleackley RC (2000) Granzyme B short-circuits the need for caspase 8 activity during granule-mediated cytotoxic T-lymphocyte killing by directly cleaving Bid. Mol Cell Biol 20:3781-3794. https://doi.org/10.1128/mcb.20.11.3781-3794.2000

26. Renvoize C, Roger R, Moulian N, Bertoglio J, Breard J (1997) Bcl-2 expression in target cells leads to functional inhibition of caspase-3 protease family in human NK and lymphokineactivated killer cell granule-mediated apoptosis. J Immunol 159:126-134

27. Sutton VR, Vaux DL, Trapani JA (1997) Bcl-2 prevents apoptosis induced by perforin and granzyme $\mathrm{B}$, but not that mediated by whole cytotoxic lymphocytes. J Immunol 158:5783-5790

28. Sharif-Askari E, Alam A, Rheaume E, Beresford PJ, Scotto C, Sharma K, Lee D, DeWolf WE, Nuttall ME, Lieberman J et al (2001) Direct cleavage of the human DNA fragmentation factor-45 by granzyme $\mathrm{B}$ induces caspase-activated DNase release and DNA fragmentation. EMBO J 20:3101-3113. https://doi.org/10.1093/ emboj/20.12.3101

29. Thomas DA, Du C, Xu M, Wang X, Ley TJ (2000) DFF45/ICAD can be directly processed by granzyme $\mathrm{B}$ during the induction of apoptosis. Immunity 12:621-632. https://doi.org/10.1016/s10747613(00)80213-7

30. Prager I, Liesche C, van Ooijen H, Urlaub D, Verron Q, Sandstrom N, Fasbender F, Claus M, Eils R, Beaudouin J et al (2019) NK cells switch from granzyme B to death receptor-mediated cytotoxicity during serial killing. J Exp Med 216:2113-2127. https:// doi.org/10.1084/jem.20181454 
31. Fulda S (2017) Smac mimetics to therapeutically target IAP proteins in cancer. Int Rev Cell Mol Biol 330:157-169. https://doi. org/10.1016/bs.ircmb.2016.09.004

32. Li R, Ruttinger D, Urba W, Fox BA, Hu HM (2004) Targeting and amplification of immune killing of tumor cells by pro-Smac. Int J Cancer 109:85-94. https://doi.org/10.1002/ijc.11655

33. Fischer K, Tognarelli S, Roesler S, Boedicker C, Schubert R, Steinle A, Klingebiel T, Bader P, Fulda S, Ullrich E (2017) The Smac mimetic BV6 improves NK cell-mediated killing of rhabdomyosarcoma cells by simultaneously targeting tumor and effector cells. Front Immunol 8:202. https://doi.org/10.3389/ fimmu.2017.00202

34. Brinkmann K, Hombach A, Seeger JM, Wagner-Stippich D, Klubertz D, Kronke M, Abken H, Kashkar H (2014) Second mitochondria-derived activator of caspase (SMAC) mimetic potentiates tumor susceptibility toward natural killer cellmediated killing. Leuk Lymphoma 55:645-651. https://doi. org/10.3109/10428194.2013.807925

35. Chen Z, Chen J, Liu H, Dong W, Huang X, Yang D, Hou J, Zhang $X$ (2018) The SMAC mimetic APG-1387 sensitizes immunemediated cell apoptosis in hepatocellular carcinoma. Front Pharmacol 9:1298. https://doi.org/10.3389/fphar.2018.01298

36. Pan W, Luo Q, Yan X, Yuan L, Yi H, Zhang L, Li B, Zhang Y, Sun J, Qiu MZ et al (2018) A novel SMAC mimetic APG-1387 exhibits dual antitumor effect on HBV-positive hepatocellular carcinoma with high expression of cIAP2 by inducing apoptosis and enhancing innate anti-tumor immunity. Biochem Pharmacol 154:127-135. https://doi.org/10.1016/j.bcp.2018.04.020

37. Czabotar PE, Lessene G, Strasser A, Adams JM (2014) Control of apoptosis by the BCL-2 protein family: implications for physiology and therapy. Nat Rev Mol Cell Biol 15:49-63. https://doi. org/10.1038/nrm 3722

38. Kehr S, Vogler M (2021) It's time to die: BH3 mimetics in solid tumors. Biochim Biophys Acta Mol Cell Res 1868:118987. https://doi.org/10.1016/j.bbamcr.2021.118987

39. Beroukhim R, Mermel CH, Porter D, Wei G, Raychaudhuri S, Donovan J, Barretina J, Boehm JS, Dobson J, Urashima M et al (2010) The landscape of somatic copy-number alteration across human cancers. Nature 463:899-905. https://doi.org/10.1038/ nature 08822

40. Oltersdorf T, Elmore SW, Shoemaker AR, Armstrong RC, Augeri DJ, Belli BA, Bruncko M, Deckwerth TL, Dinges J, Hajduk PJ et al (2005) An inhibitor of Bcl-2 family proteins induces regression of solid tumours. Nature 435:677-681

41. Roberts AW, Davids MS, Pagel JM, Kahl BS, Puvvada SD, Gerecitano JF, Kipps TJ, Anderson MA, Brown JR, Gressick L et al (2016) Targeting BCL2 with Venetoclax in Relapsed Chronic Lymphocytic Leukemia. N Engl J Med 374:311-322. https://doi.org/10.1056/NEJMoa1513257

42. VanDerMeid KR, Elliott MR, Baran AM, Barr PM, Chu CC, Zent CS (2018) Cellular cytotoxicity of next-generation CD20 monoclonal antibodies. Cancer Immunol Res 6:1150-1160. https://doi.org/10.1158/2326-6066.CIR-18-0319

43. Seymour JF, Kipps TJ, Eichhorst B, Hillmen P, D'Rozario J, Assouline S, Owen C, Gerecitano J, Robak T, De la Serna J et al (2018) Venetoclax-rituximab in relapsed or refractory chronic lymphocytic leukemia. N Engl J Med 378:1107-1120. https:// doi.org/10.1056/NEJMoa1713976

44. Enqvist M, Jacobs B, Junlen HR, Schaffer M, Melen CM, Friberg D, Wahlin BE, Malmberg KJ (2019) Systemic and intra-nodal activation of NK cells after rituximab monotherapy for follicular lymphoma. Front Immunol 10:2085. https://doi.org/10.3389/ fimmu.2019.02085

45. Du J, Lopez-Verges S, Pitcher BN, Johnson J, Jung SH, Zhou L, Hsu K, Czuczman MS, Cheson B, Kaplan L et al (2014) CALGB 150905 (Alliance): rituximab broadens the antilymphoma response by activating unlicensed NK cells. Cancer Immunol Res 2:878-889. https://doi.org/10.1158/2326-6066.CIR-13-0158

46. Moga E, Alvarez E, Canto E, Vidal S, Rodriguez-Sanchez JL, Sierra J, Briones J (2008) NK cells stimulated with IL-15 or CpG ODN enhance rituximab-dependent cellular cytotoxicity against B-cell lymphoma. Experimental hematology 36:69-77. https:// doi.org/10.1016/j.exphem.2007.08.012

47. Dai YJ, He SY, Hu F, Li XP, Zhang JM, Chen SL, Zhang WN, Sun HM, Wang DW (2021) Bone marrow infiltrated natural killer cells predicted the anti-leukemia activity of MCL1 or BCL2 inhibitors in acute myeloid leukemia. Mol Cancer 20:8. https:// doi.org/10.1186/s12943-020-01302-6

48. Aubrey BJ, Kelly GL, Janic A, Herold MJ, Strasser A (2018) How does p53 induce apoptosis and how does this relate to p53-mediated tumour suppression? Cell death and differentiation 25:104-113. https://doi.org/10.1038/cdd.2017.169

49. Liu Y, Wang X, Wang G, Yang Y, Yuan Y, Ouyang L (2019) The past, present and future of potential small-molecule drugs targeting p53-MDM2/MDMX for cancer therapy. Eur J Med Chem 176:92-104. https://doi.org/10.1016/j.ejmech.2019.05.018

50. Veneziani I, Infante P, Ferretti E, Melaiu O, Battistelli C, Lucarini V, Compagnone M, Nicoletti C, Castellano A, Petrini $S$ et al (2021) Nutlin-3a enhances natural killer cell-mediated killing of neuroblastoma by restoring p53-dependent expression of ligands for NKG2D and DNAM-1 receptors. Cancer Immunol Res 9:170-183. https://doi.org/10.1158/2326-6066.CIR-20-0313

51. Textor S, Fiegler N, Arnold A, Porgador A, Hofmann TG, Cerwenka A (2011) Human NK cells are alerted to induction of p53 in cancer cells by upregulation of the NKG2D ligands ULBP1 and ULBP2. Cancer Res 71:5998-6009. https://doi.org/10.1158/ 0008-5472.CAN-10-3211

52. Sheppard S, Schuster IS, Andoniou CE, Cocita C, Adejumo T, Kung SKP, Sun JC, Degli-Esposti MA, Guerra N (2018) The murine natural cytotoxic receptor NKp46/NCR1 controls TRAIL protein expression in NK cells and ILC1s. Cell Rep 22:33853392. https://doi.org/10.1016/j.celrep.2018.03.023

53. Wajant H (2019) Molecular mode of action of TRAIL receptor agonists-common principles and their translational exploitation. Cancers (Basel) 11. https://doi.org/10.3390/cancers11070954

54. Mohr A, Chu T, Brooke GN, Zwacka RM (2019) MSC.sTRAIL has better efficacy than MSC.FL-TRAIL and in combination with AKTi blocks pro-metastatic cytokine production in prostate cancer cells. Cancers (Basel) 11. https://doi.org/10.3390/cancers11040568

55. von Karstedt S, Montinaro A, Walczak H (2017) Exploring the TRAILs less travelled: TRAIL in cancer biology and therapy. Nat Rev Cancer 17:352-366. https://doi.org/10.1038/nrc.2017.28

56. Graves JD, Kordich JJ, Huang TH, Piasecki J, Bush TL, Sullivan T, Foltz IN, Chang W, Douangpanya H, Dang T et al (2014) Apo2L/TRAIL and the death receptor 5 agonist antibody AMG 655 cooperate to promote receptor clustering and antitumor activity. Cancer Cell 26:177-189. https://doi.org/10.1016/j.ccr. 2014.04.028

57. El-Gazzar A, Perco P, Eckelhart E, Anees M, Sexl V, Mayer B, Liu Y, Mikulits W, Horvat R, Pangerl T et al (2010) Natural immunity enhances the activity of a DR5 agonistic antibody and carboplatin in the treatment of ovarian cancer. Molecular cancer therapeutics 9:1007-1018. https://doi.org/10.1158/1535-7163. MCT-09-0933

58. Sheard MA, Asgharzadeh S, Liu Y, Lin TY, Wu HW, Ji L, Groshen S, Lee DA, Seeger RC (2013) Membrane-bound TRAIL supplements natural killer cell cytotoxicity against neuroblastoma cells. J Immunother 36:319-329. https://doi.org/10.1097/ CJI.0b013e31829b4493

59. Kandoth C, McLellan MD, Vandin F, Ye K, Niu B, Lu C, Xie M, Zhang Q, McMichael JF, Wyczalkowski MA et al (2013) 
Mutational landscape and significance across 12 major cancer types. Nature 502:333-339. https://doi.org/10.1038/nature12634

60. Bates SE (2020) Epigenetic Therapies for Cancer. N Engl J Med 383:650-663. https://doi.org/10.1056/NEJMra1805035

61. Dohner H, Estey E, Grimwade D, Amadori S, Appelbaum FR, Buchner T, Dombret H, Ebert BL, Fenaux P, Larson RA et al (2017) Diagnosis and management of AML in adults: 2017 ELN recommendations from an international expert panel. Blood 129:424-447. https://doi.org/10.1182/blood-2016-08-733196

62. Topper MJ, Vaz M, Marrone KA, Brahmer JR, Baylin SB (2020) The emerging role of epigenetic therapeutics in immuno-oncology. Nat Rev Clin Oncol 17:75-90. https://doi. org/10.1038/s41571-019-0266-5

63. Cany J, Roeven MWH, Hoogstad-van Evert JS, Hobo W, Maas F, Franco Fernandez R, Blijlevens NMA, van der Velden WJ, Huls G, Jansen JH et al (2018) Decitabine enhances targeting of AML cells by CD34(+) progenitor-derived NK cells in NOD/SCID/ IL2Rg(null) mice. Blood 131:202-214. https://doi.org/10.1182/ blood-2017-06-790204

64. Vasu S, He S, Cheney C, Gopalakrishnan B, Mani R, Lozanski G, Mo X, Groh V, Whitman SP, Konopitzky R et al (2016) Decitabine enhances anti-CD33 monoclonal antibody BI 836858-mediated natural killer ADCC against AML blasts. Blood 127:2879-2889. https://doi.org/10.1182/blood-2015-11-680546

65. Wiencke JK, Butler R, Hsuang G, Eliot M, Kim S, Sepulveda MA, Siegel D, Houseman EA, Kelsey KT (2016) The DNA methylation profile of activated human natural killer cells. Epigenetics 11:363-380. https://doi.org/10.1080/15592294.2016. 1163454

66. Schmiedel BJ, Arelin V, Gruenebach F, Krusch M, Schmidt SM, Salih HR (2011) Azacytidine impairs NK cell reactivity while decitabine augments NK cell responsiveness toward stimulation. Int J Cancer 128:2911-2922. https://doi.org/10.1002/ijc.25635

67. Gao XN, Lin J, Wang LL, Yu L (2009) Demethylating treatment suppresses natural killer cell cytolytic activity. Mol Immunol 46:2064-2070. https://doi.org/10.1016/j.molimm.2009.02.033

68. Climent N, Plana M (2019) Immunomodulatory Activity of Tyrosine Kinase Inhibitors to Elicit Cytotoxicity Against Cancer and Viral Infection. Front Pharmacol 10:1232. https://doi.org/10. 3389/fphar.2019.01232

69. Chang MC, Cheng HI, Hsu K, Hsu YN, Kao CW, Chang YF, Lim KH, Chen CG (2018) NKG2A down-regulation by dasatinib enhances natural killer cytotoxicity and accelerates effective treatment responses in patients with chronic myeloid leukemia. Front Immunol 9:3152. https://doi.org/10.3389/fimmu.2018. 03152

70. Uchiyama T, Sato N, Narita M, Yamahira A, Iwabuchi M, Furukawa T, Sone H, Takahashi M (2013) Direct effect of dasatinib on proliferation and cytotoxicity of natural killer cells in in vitro study. Hematol Oncol 31:156-163. https://doi.org/10.1002/hon.2034

71. Hassold N, Seystahl K, Kempf K, Urlaub D, Zekl M, Einsele H, Watzl C, Wischhusen J, Seggewiss-Bernhardt R (2012) Enhancement of natural killer cell effector functions against selected lymphoma and leukemia cell lines by dasatinib. Int J Cancer 131:E916-927. https://doi.org/10.1002/ijc.27537

72. Iriyama N, Fujisawa S, Yoshida C, Wakita H, Chiba S, Okamoto S, Kawakami K, Takezako N, Kumagai T, Inokuchi K et al (2015) Early cytotoxic lymphocyte expansion contributes to a deep molecular response to dasatinib in patients with newly diagnosed chronic myeloid leukemia in the chronic phase: results of the D-first study. Am J Hematol 90:819-824. https://doi.org/10.1002/ajh.24096

73. Mizoguchi I, Yoshimoto T, Katagiri S, Mizuguchi J, Tauchi T, Kimura Y, Inokuchi K, Ohyashiki JH, Ohyashiki K (2013) Sustained upregulation of effector natural killer cells in chronic myeloid leukemia after discontinuation of imatinib. Cancer Sci 104:1146-1153. https://doi.org/10.1111/cas.12216
74. Hara R, Onizuka M, Matsusita E, Kikkawa E, Nakamura Y, Matsushita H, Ohgiya D, Murayama H, Machida S, Ohmachi $\mathrm{K}$ et al (2017) NKG2D gene polymorphisms are associated with disease control of chronic myeloid leukemia by dasatinib. Int J Hematol 106:666-674. https://doi.org/10.1007/ s12185-017-2294-1

75. Ruscetti M, Leibold J, Bott MJ, Fennell M, Kulick A, Salgado NR, Chen CC, Ho YJ, Sanchez-Rivera FJ, Feucht J et al (2018) NK cell-mediated cytotoxicity contributes to tumor control by a cytostatic drug combination. Science 362:1416-1422. https:// doi.org/10.1126/science.aas 9090

76. Lohmeyer J, Nerreter T, Dotterweich J, Einsele H, SeggewissBernhardt R (2018) Sorafenib paradoxically activates the RAS/ RAF/ERK pathway in polyclonal human NK cells during expansion and thereby enhances effector functions in a doseand time-dependent manner. Clin Exp Immunol 193:64-72. https://doi.org/10.1111/cei.13128

77. Kamiya T, Chang YH, Campana D (2016) Expanded and Activated Natural Killer Cells for Immunotherapy of Hepatocellular Carcinoma. Cancer Immunol Res 4:574-581. https://doi. org/10.1158/2326-6066.CIR-15-0229

78. Hage C, Hoves S, Strauss L, Bissinger S, Prinz Y, Poschinger T, Kiessling F, Ries CH (2019) Sorafenib induces pyroptosis in macrophages and triggers natural killer cell-mediated cytotoxicity against hepatocellular carcinoma. Hepatology 70:1280-1297. https://doi.org/10.1002/hep.30666

79. Kronke J, Fink EC, Hollenbach PW, MacBeth KJ, Hurst SN, Udeshi ND, Chamberlain PP, Mani DR, Man HW, Gandhi AK et al (2015) Lenalidomide induces ubiquitination and degradation of CK1alpha in del(5q) MDS. Nature 523:183-188. https://doi.org/10.1038/nature14610

80. Gandhi AK, Kang J, Havens CG, Conklin T, Ning Y, Wu L, Ito T, Ando H, Waldman MF, Thakurta A et al (2014) Immunomodulatory agents lenalidomide and pomalidomide costimulate $\mathrm{T}$ cells by inducing degradation of $\mathrm{T}$ cell repressors Ikaros and Aiolos via modulation of the E3 ubiquitin ligase complex CRL4(CRBN.). Br J Haematol 164:811-821. https:// doi.org/10.1111/bjh.12708

81. Kronke J, Udeshi ND, Narla A, Grauman P, Hurst SN, McConkey M, Svinkina T, Heckl D, Comer E, Li X et al (2014) Lenalidomide causes selective degradation of IKZF1 and IKZF3 in multiple myeloma cells. Science 343:301-305. https://doi.org/10.1126/ science. 1244851

82. Hideshima T, Ogiya D, Liu J, Harada T, Kurata K, Bae J, Massefski W, Anderson KC (2021) Immunomodulatory drugs activate NK cells via both Zap-70 and cereblon-dependent pathways. Leukemia 35:177-188. https://doi.org/10.1038/ s41375-020-0809-x

83. Hayashi T, Hideshima T, Akiyama M, Podar K, Yasui H, Raje N, Kumar S, Chauhan D, Treon SP, Richardson P et al (2005) Molecular mechanisms whereby immunomodulatory drugs activate natural killer cells: clinical application. Br J Haematol 128:192-203. https://doi.org/10.1111/j.1365-2141.2004.05286.x

84. Payvandi F, Wu L, Naziruddin SD, Haley M, Parton A, Schafer PH, Chen RS, Muller GW, Hughes CC, Stirling DI (2005) Immunomodulatory drugs (IMiDs) increase the production of IL-2 from stimulated $T$ cells by increasing PKC-theta activation and enhancing the DNA-binding activity of AP-1 but not NF-kappaB, OCT-1, or NF-AT. J Interferon Cytokine Res 25:604-616. https://doi.org/10.1089/jir.2005.25.604

85. Reddy N, Hernandez-Ilizaliturri FJ, Deeb G, Roth M, Vaughn M, Knight J, Wallace P, Czuczman MS (2008) Immunomodulatory drugs stimulate natural killer-cell function, alter cytokine production by dendritic cells, and inhibit angiogenesis enhancing the anti-tumour activity of rituximab in vivo. Br J Haematol 140:36-45. https://doi.org/10.1111/j.1365-2141.2007.06841.x 
86. Fionda C, Abruzzese MP, Zingoni A, Cecere F, Vulpis E, Peruzzi G, Soriani A, Molfetta R, Paolini R, Ricciardi MR et al (2015) The IMiDs targets IKZF-1/3 and IRF4 as novel negative regulators of $\mathrm{NK}$ cell-activating ligands expression in multiple myeloma. Oncotarget 6:23609-23630. https://doi. org/10.18632/oncotarget.4603

87. Le Roy A, Prebet T, Castellano R, Goubard A, Riccardi F, Fauriat C, Granjeaud S, Benyamine A, Castanier C, Orlanducci F et al (2018) Immunomodulatory drugs exert anti-leukemia effects in acute myeloid leukemia by direct and immunostimulatory activities. Front Immunol 9:977. https://doi.org/10.3389/fimmu.2018.00977

88. Tai YT, Li XF, Catley L, Coffey R, Breitkreutz I, Bae J, Song W, Podar K, Hideshima T, Chauhan D et al (2005) Immunomodulatory drug lenalidomide (CC-5013, IMiD3) augments anti-CD40 SGN-40-induced cytotoxicity in human multiple myeloma: clinical implications. Cancer Res 65:11712-11720. https://doi.org/10. 1158/0008-5472.CAN-05-1657

89. Gorgun G, Calabrese E, Soydan E, Hideshima T, Perrone G, Bandi M, Cirstea D, Santo L, Hu Y, Tai YT et al (2010) Immunomodulatory effects of lenalidomide and pomalidomide on interaction of tumor and bone marrow accessory cells in multiple myeloma. Blood 116:3227-3237. https://doi.org/10.1182/ blood-2010-04-279893

90. Lagrue K, Carisey A, Morgan DJ, Chopra R, Davis DM (2015) Lenalidomide augments actin remodeling and lowers NK-cell activation thresholds. Blood 126:50-60. https://doi.org/10.1182/ blood-2015-01-625004

91. Khaznadar Z, Henry G, Setterblad N, Agaugue S, Raffoux E, Boissel N, Dombret H, Toubert A, Dulphy N (2014) Acute myeloid leukemia impairs natural killer cells through the formation of a deficient cytotoxic immunological synapse. Eur J Immunol 44:3068-3080. https://doi.org/10.1002/eji.201444500

92. Lioznov M, El-Cheikh J Jr, Hoffmann F, Hildebrandt Y, Ayuk F, Wolschke C, Atanackovic D, Schilling G, Badbaran A, Bacher U et al (2010) Lenalidomide as salvage therapy after allo-SCT for multiple myeloma is effective and leads to an increase of activated NK $(\mathrm{NKp} 44(+))$ and T (HLA-DR(+)) cells. Bone Marrow Transplant 45:349-353. https://doi.org/10.1038/bmt.2009.155

93. Hagner PR, Chiu H, Ortiz M, Apollonio B, Wang M, Couto S, Waldman MF, Flynt E, Ramsay AG, Trotter M et al (2017) Activity of lenalidomide in mantle cell lymphoma can be explained by NK cell-mediated cytotoxicity. Br J Haematol 179:399-409. https://doi.org/10.1111/bjh.14866

94. Dermani FK, Samadi P, Rahmani G, Kohlan AK, Najafi R (2019) PD-1/PD-L1 immune checkpoint: potential target for cancer therapy. J Cell Physiol 234:1313-1325. https://doi.org/10.1002/jcp. 27172

95. Pesce S, Greppi M, Grossi F, Del Zotto G, Moretta L, Sivori S, Genova C, Marcenaro E (2019) PD/1-PD-Ls checkpoint: insight on the potential role of NK cells. Front Immunol 10:1242. https:// doi.org/10.3389/fimmu.2019.01242

96. Hsu J, Hodgins JJ, Marathe M, Nicolai CJ, Bourgeois-Daigneault MC, Trevino TN, Azimi CS, Scheer AK, Randolph HE, Thompson TW et al (2018) Contribution of NK cells to immunotherapy mediated by PD-1/PD-L1 blockade. J Clin Invest 128:4654-4668. https://doi. org/10.1172/JCI99317

97. Poznanski SM, Ritchie TM, Fan IY, El-Sayes A, Portillo AL, Ben-Avi R, Rojas EA, Chew MV, Shargall Y, Ashkar AA (2021) Expanded human NK cells from lung cancer patients sensitize patients' PDL1-negative tumors to PD1-blockade therapy. J Immunother Cancer 9. https://doi.org/10.1136/jitc-2020-001933

98. Julia EP, Amante A, Pampena MB, Mordoh J, Levy EM (2018) Avelumab, an IgG1 anti-PD-L1 immune checkpoint inhibitor, triggers NK cell-mediated cytotoxicity and cytokine production against triple negative breast cancer cells. Front Immunol 9:2140. https://doi.org/10.3389/fimmu.2018.02140
99. Lin M, Luo H, Liang S, Chen J, Liu A, Niu L, Jiang Y (2020) Pembrolizumab plus allogeneic NK cells in advanced non-small cell lung cancer patients. J Clin Invest 130:2560-2569. https:// doi.org/10.1172/JCI132712

100. Wan C, Keany MP, Dong H, Al-Alem LF, Pandya UM, Lazo S, Boehnke K, Lynch KN, Xu R, Zarrella DT et al (2021) Enhanced efficacy of simultaneous PD-1 and PD-L1 immune checkpoint blockade in high-grade serous ovarian cancer. Cancer Res 81:158-173. https://doi.org/10.1158/0008-5472.CAN-20-1674

101. Kotanides H, Li Y, Malabunga M, Carpenito C, Eastman SW, Shen Y, Wang G, Inigo I, Surguladze D, Pennello AL et al (2020) Bispecific targeting of PD-1 and PD-L1 enhances T-cell activation and antitumor immunity. Cancer Immunol Res 8:1300-1310. https://doi.org/10.1158/2326-6066.CIR-20-0304

102. Ribas A, Kefford R, Marshall MA, Punt CJ, Haanen JB, Marmol M, Garbe C, Gogas H, Schachter J, Linette G et al (2013) Phase III randomized clinical trial comparing tremelimumab with standardof-care chemotherapy in patients with advanced melanoma. J Clin Oncol : Official J Am Soc Clin Oncol 31:616-622. https://doi.org/ 10.1200/JCO.2012.44.6112

103. Robert C, Thomas L, Bondarenko I, O’Day S, Weber J, Garbe C, Lebbe C, Baurain JF, Testori A, Grob JJ et al (2011) Ipilimumab plus dacarbazine for previously untreated metastatic melanoma. $\mathrm{N}$ Engl J Med 364:2517-2526. https://doi.org/10.1056/NEJMoa1104621

104. Passariello M, Camorani S, Vetrei C, Ricci S, Cerchia L, De Lorenzo C (2020) Ipilimumab and its derived EGFR aptamer-based conjugate induce efficient NK cell activation against cancer cells. Cancers (Basel) 12. https://doi.org/10.3390/cancers12020331

105. Sanseviero E, O'Brien EM, Karras JR, Shabaneh TB, Aksoy BA, Xu W, Zheng C, Yin X, Xu X, Karakousis GC et al (2019) Anti-CTLA-4 activates intratumoral NK cells and combined with IL15/IL15Ralpha complexes enhances tumor control. Cancer Immunol Res 7:1371-1380. https://doi.org/10.1158/2326-6066. CIR-18-0386

106. Deuse T, Hu X, Agbor-Enoh S, Jang MK, Alawi M, Saygi C, Gravina A, Tediashvili G, Nguyen VQ, Liu Y et al (2021) The SIRPalpha-CD47 immune checkpoint in NK cells. J Exp Med 218. https://doi.org/10.1084/jem.20200839

107. Han D, Xu Y, Zhao X, Mao Y, Kang Q, Wen W, Yu X, Xu L, Liu $F$, Zhang $M$ et al (2021) A novel human anti-TIGIT monoclonal antibody with excellent function in eliciting NK cell-mediated antitumor immunity. Biochem Biophys Res Commun 534:134140. https://doi.org/10.1016/j.bbrc.2020.12.013

108. Ng W, Gong C, Yan X, Si G, Fang C, Wang L, Zhu X, Xu Z, Yao C, Zhu S (2021) Targeting CD155 by rediocide-A overcomes tumour immuno-resistance to natural killer cells. Pharm Biol 59:47-53. https://doi.org/10.1080/13880209.2020.1865410

109. Heinze A, Grebe B, Bremm M, Huenecke S, Munir TA, Graafen L, Frueh JT, Merker M, Rettinger E, Soerensen J et al (2019) The Synergistic Use of IL-15 and IL-21 for the generation of $\mathrm{NK}$ cells from $\mathrm{CD} 3 / \mathrm{CD} 19$-depleted grafts improves their ex vivo expansion and cytotoxic potential against neuroblastoma: perspective for optimized immunotherapy post haploidentical stem cell transplantation. Front Immunol 10:2816. https://doi.org/10. 3389/fimmu.2019.02816

110. Albinger N, Hartmann J, Ullrich E (2021) Current status and perspective of CAR-T and CAR-NK cell therapy trials in Germany. Gene Ther. https://doi.org/10.1038/s41434-021-00246-w

111. Lazarova M, Wels WS, Steinle A (2020) Arming cytotoxic lymphocytes for cancer immunotherapy by means of the NKG2D/ NKG2D-ligand system. Expert Opin Biol Ther 20:1491-1501. https://doi.org/10.1080/14712598.2020.1803273

Publisher's Note Springer Nature remains neutral with regard to jurisdictional claims in published maps and institutional affiliations. 